BIZARI, DR; CARDOSO, JC. 2016. Reuse water and urban horticulture: alliance towards more sustainable cities. Horticultura Brasileira $34:$ 311-317. DOI - http://dx.doi.org/10.1590/S0102-05362016003002

\title{
Reuse water and urban horticulture: alliance towards more sustainable cities
}

\author{
Douglas R Bizari; Jean C Cardoso \\ Universidade Federal de São Carlos, Departamento de Desenvolvimento Rural (UFSCar-CCA), 13600-970 Araras-SP, Brasil; \\ douglasbizari@gmail.com; jeancardctv@gmail.com
}

\begin{abstract}
The need to rethink current models of using water resources in the various sectors of human activity is escalating, as thousands of people in different regions of the world are suffering from clean water shortage for their basic daily needs. In this context, the use of recycled water from treated domestic sewage in agricultural activities is gaining ground. Reuse water can combine environmental protection and high agricultural productivity, especially for simultaneously carrying plant nutrients and minimizing demands for catching "noble" fresh water from streams and water sources for irrigation, currently the highest water consuming activity. The increasing urbanization contributes to generate, but also to foster the treatment and use of wastewater, since urban areas are, at one time, chief water consumers and chief sewage producers. Although there are cultural and sanitary impediments for using recycled water on large scale and the knowledge about possible existing treatments is still limited, a safe alternative to integrate the reuse water into the productive process is its use in irrigation projects involving non edible species. Among these, plants used in floriculture and landscaping can be great allies for the development of wastewater-based urban and peri-urban horticulture, encouraging local development, creating jobs and aiding to environmental protection. We critically discuss these possibilities in this article.
\end{abstract}

Keywords: reuse, recycled wastewater, irrigation, sustainability, urban and peri-urban horticulture, ornamental plants.

\begin{abstract}
RESUMO
Água de reuso e horticultura urbana: aliança para a criação de cidades mais sustentáveis
\end{abstract}

A necessidade de se repensar os modelos atuais de uso dos recursos hídricos nos diversos setores da atividade humana é cada vez maior, uma vez que milhares de pessoas de diversas regiões do mundo vêm sofrendo com a falta de água para suas necessidades básicas do dia-a-dia. Neste contexto, a utilização da água de reuso de esgoto doméstico tratado nas atividades agrícolas vem ganhando espaço. A água de reuso pode aliar preservação ambiental e alta produtividade agrícola, principalmente por já conter nutrientes para as plantas e por minimizar a pressão sobre a retirada de água "nobre" de rios e mananciais para a irrigação, que é a maior consumidora de água na atualidade. A crescente urbanização contribui para a geração, mas também para estimular o tratamento e uso de águas residuais, uma vez que áreas urbanas são, a um só tempo, grandes consumidoras de água e grandes produtoras de esgoto. Embora existam impedimentos culturais e sanitários para a utilização da água de reuso em larga escala e de ser limitado o conhecimento sobre os possíveis tratamentos existentes para tal finalidade, uma alternativa segura para integrar a água de reuso ao processo produtivo é sua utilização em projetos de irrigação que considerem espécies não comestíveis. Entre essas, plantas utilizadas na floricultura e no paisagismo podem ser grandes aliadas para o desenvolvimento da horticultura urbana e periurbana com o uso de águas residuais, de modo a promover o desenvolvimento local, gerar empregos e preservar o meio ambiente. Neste artigo, são avaliadas de forma crítica essas possibilidades.

Palavras-chave: água de reuso, água reciclada, irrigação, sustentabilidade, horticultura urbana e periurbana, plantas ornamentais.

\section{(Recebido para publicação em 7 de março de 2016; aceito em 27 de junho de 2016) (Received on March 7, 2016; accepted on June 27, 2016)}

\begin{abstract}
Reuse water as an alternative water source for agricultural production

Whereas irrigated agriculture is the highest water demanding activity in the world, on average $70 \%$ of the total volume of water collected is used in agriculture to produce food, energy, fiber and others; there is growing and genuine interest in the use of recycled water from treated sewage as an alternative
\end{abstract}

water source for irrigation. In addition to reduce demands over clean waters, reuse water is regularly available around the year and sewage effluents can also play a role as nutrient sources for plants. Developing regions, including Africa and Asia, are facing a fast urbanization process, which is expected to accelerate even more in coming decades, doubling the urban population between 2000 and
2030 (Sagasta et al., 2013). In 2030, nearly five billion people, or almost $60 \%$ of the world population, will be living in large urban centers (UNO, 2006).

The increasing urbanization significantly affects the generation, treatment and use of wastewater, since urban areas are its main producers. Cities often discharge their untreated or partially treated wastewater into 
the environment, polluting traditional irrigation water sources and leading to the degradation of the available freshwater resources, which could be useful for urban and peri-urban agriculture (Raschid-Sally \& Jayacody, 2008). Considering a per capita sewage contribution of 150-200 L/hab/day and a generic demand of 1000-2000 mm/ $\mathrm{yr}$, it is estimated that the reuse water produced by 50,000-inhabitant city would irrigate around 200 ha (Bastos, 1999).

Along with the issues of water use for agricultural purposes, urban and peri-urban agriculture have, and will continue to have, a key role in producing and supplying food to cities, especially vegetables. Nevertheless, yields in agriculture are directly dependent on the timely supply of water, in the required volumes, further increasing the pressure over water demand. With the deteriorating water crisis in several regions of major agricultural and horticultural importance, often due to climate changes, as recently observed in Southeastern Brazil, water availability is a constant concern. The issue turns from be urgent nowadays to become critical for future generations in different regions of the world. This leads us to the need to adopt measures to reuse water, aiming at ensuring water availability, today and tomorrow.

Considering the actual scenario, the "source replacement" concept (Hespanhol, 2002) appears as an interesting alternative to meet less noble water demands, preserving the best quality water for specific uses, such as human and domestic supply. According to Hespanhol (2002), the use of wastewater in crop irrigation increased significantly due to the following factors:

- Difficulties in identifying alternative sources of water for irrigation;

- Increasing acknowledgment of water resources management bodies of the potential and relevance of reuse water;

- Growing socio-cultural acceptance of reuse water practices in agriculture;

- Mounting confidence on the minimal risks of reuse water to public health and to the environment when adequate precaution measures are effectively taken;

- High cost of fertilizers, and;

- High costs of sewage treatment for discharge into watercourses;

Although the use of treated sewage water in irrigation turns out to be simultaneously an effective way to mitigate pollution in water streams and increase water availability, which is especially relevant in arid and semi-arid, in Brazil the population poses several restrictions to agricultural products grown this way. Brazilian regulation does not allow the use of effluent water in vegetable production in hydroponics and therefore there are no standards for microbiological parameters in this production system whatsoever. However, even if the regulation were there, how to convince people to purchase the daily lettuce and tomato when they carry a 'irrigated with water from treated sewage' tag?

Different studies, in both hydroponics and soil, confirm that the use of wastewater in agriculture is safe. Although there is always the possibility for contact between leaves and fruits and pathogenic microorganisms, contamination levels have consistently fallen within the acceptable limits for consumption. For example, Sousa et al. (2006) observed that although pepper grown in soil conditions furrowirrigated with water from UASB (Upflow Anaerobic Sludge Blanket) yielded slightly below plants irrigated with water from artesian well, fruit quality was just the same. There was fruit contamination, but levels were within the acceptable limits for consumption and did not differ from fruits sold at retail, irrigated with clean water.

In hydroponic lettuce grown with sewage reuse water, Cuba et al. (2015) found no thermotolerant microorganisms (Escherichia coli) in plants and, although all samples were positive to total coliforms, counts were low [Resolution of the Executive Board no 12, January 2, 2001, Brazilian National Health Surveillance
Agency (ANVISA)], always below $10^{2}$ thermotolerant coliforms, the upper limit for fresh, prepared, sanitized, chilled or frozen vegetables for direct consumption in Brazil (ANVISA, 2001). These authors found 87.5 and $93.7 \mathrm{cfu} / \mathrm{mL}$ in treatments with reuse water and fertilizer and only reuse of water, respectively.

Interesting, vegetables irrigated conventionally and sold in retails have contamination levels much higher than the regulation limits. Cuba et al. (2015), although finding Escherichia coli in the wastewater used for lettuce irrigation in hydroponics, did not observe the bacteria when analyzing leaves, probably because (1) there was no direct contact among leaves and water during plant development, and (2) proper care was observed during harvest to avoid contact between roots and leaves.

Still, these evidences do not seem to be enough to convince researchers themselves to consume these products and, to a much less extent, final consumers. However, it is noteworthy that many farmers installed downstream water sources may be inadvertently catching bad quality water, resulting from inadequate sewage treatment, and using it to produce vegetables. Guimarães et al. (2003) found high coliform concentration and parasitological forms of animal or human origin in lettuce samples commercialized in the city of Lavras, state of Minas Gerais. Tresseler et al. (2009) studied the microbiological quality of fresh-cut vegetables and found some samples unsuitable for human consumption due to the presence of Salmonella sp. In Brazil, similar situation should occur in vegetables sold in markets and supermarkets in various regions, since quality control for vegetables is still short in the country and pathogenic organisms are commonly present in irrigation water. The Environmental Company of the state of São Paulo (CETESB, 2001) allows the use of wastewater only in sports fields, public parks, cereals and crops meant for industrialization, forestry, and forage for hay and silage. 
Regardless of total and thermotolerant (Escherichia coli) coliform counts, the use of wastewater to grow vegetables is not allowed yet (Cuba et al., 2015).

The World Health Organization (WHO, 1989) has recommendations on the microbiological quality of wastewater for agriculture (Table 1). For safe food production, with health quality, WHO recommends that reuse water for irrigating crops to be consumed in natura should have a maximum of 1 helminth egg per liter and 1,000 MPN (most probable number) of coliforms per $100 \mathrm{~mL}$. Due to these health limits, raw wastewater has necessarily to be treated before it is suitable for using, for example, in vegetable production. Some methods of sewage treatment to clean the water and make it adequate for agriculture were already developed and are effective in reducing the water microbial load.

\section{Ornamental plants: a viable alternative for reuse water}

The irrigation of plants intended for purposes other than food production, such as oils for biodiesel, forestry, sugarcane for energy and ornamentals is a safe alternative for the use of wastewater in agriculture, also because there is absolutely no need of clean water to irrigate this set of crops. In addition, directing reuse water to this end helps in mitigating the severe environmental impacts caused by sewage effluents, often directed, treated or not, to watercourses that run through cities and agglomerations.

We also must take into account the weather conditions, especially due to the rain irregularity observed in recent years which can lead to the depletion of reservoirs used for supply water to large cities to critical levels. Strong variability in precipitation standards enhances significantly the competition for clean water, which must be indisputably used in a priority basis for human consumption and, only then, for producing food that is consumed in natura, such as vegetables. Vegetables come mainly from city green belts, both in big cities like São Paulo, in Brazil, as in smaller towns. An example of how serious this situation can be was the competition for water in 2014 and 2015 in Southeast and Mid-West Brazil, when rains were very scarce for two subsequent years (situation that persists in 2016 in some regions). In those years, the press carried out a broad coverage on water needs per $\mathrm{kg}$ of food produced and the news turned many vegetables into villains of water consumption.

High water demands, coupled with significant losses on outdated and worn irrigation systems, lack of control of water volume and quality and vegetable losses during production, transportation, storage and marketing, pose a strong questioning on the sustainability of current production systems, specifically in relation their huge water demands. Among the alternatives towards a smarter water use, we can name:

- Increases in the water use efficiency through modern and innovative irrigation methods (Levidow et al., 2014);

- Replacement of current cultivars, as reported in strawberries (MartínezFerri et al., 2016), or current crops by others with high water use efficiency;

- Breeding for plant efficiency in water uptake and use through either conventional or biotechnological methods, and;

- Use of less noble water sources for irrigation, such as reuse and recycling wastewater and salt water (Sousa et al., 2006; Ladeiro, 2012).

Considering the later topic, if society is not comfortable with the use of recycled water to produce food, even when involving plants of high nutritional value, as it is the case for vegetables, the production of plants intended for other purposes might take the stage. Flowers and ornamentals, including for landscaping, though not frequently remembered, are a real and immediate option to enable the use of less noble waters in controlled production systems aimed at reducing the demand over clean water. Additionally, this use also serves as a means for reducing the domestic sewage load on waterways, adding to the mitigation of environmental impacts.

Last, we must also discuss the use of wastewater to irrigate crops that cover larger areas, for example industrial crops and grains. Although possible, this use is hampered by the need of carrying large volumes generated in cities to producing regions, usually more distant from urban centers. Nevertheless, either because of water demands for irrigation or because of the need to reduce pollution load over water sources, this is an use for wastewater that has to be addressed in coming decades. Depending on the solutions developed, it might enable the broadening of agricultural systems based in reuse water as irrigation source. A good way to start would be crops intended to biofuel production.

\section{New paths for urban and peri- urban horticulture}

Urban and peri-urban horticulture may stimulate and facilitate the use of recycled water in marginal areas of large urban centers. Many cities already foster the activity. São Paulo created the City Urban and Peri-Urban Agriculture Program (municipal law 13,727/2004), which, by means of the implementing decree 51.810/2010, indicates that agroecological production systems should be the program main focus. It is important to stress that urban and peri-urban horticulture should gain more importance in coming years, as they are expected to grow based on mainly sustainable and efficient production systems, including reuse water for irrigation (De Bon et al., 2010). Still considering the Brazilian experience, it is also necessary to bring to the spot the National Irrigation Policy (Law n⿳亠口冋.12,787/2013), which provides the implementation of public irrigation projects in line with family farming, due to its social relevance. It is worth remembering that under this policy, item II indicates that farmers should "adopt practices and techniques for irrigation and drainage that promote the conservation of environmental resources, especially soil and water resources". Taking into account this legal framework, projects involving the production of flowers and other ornamental species to urban 


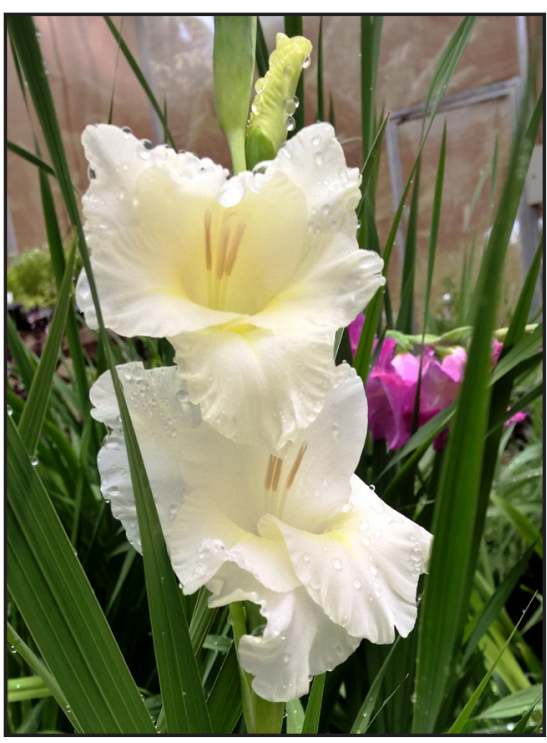

Figure 1. Close-up of Gladiolus flowers grown with reuse water (detalhe de flores de gladíolo cultivadas com água de reuso). Araras, UFSCar-CCA, 2016.

landscaping and gardens or afforestation do encourage the development of sustainable urban horticulture and create actual alternatives for using treated sewage wastewater.

The use of recycled water could result in projects containing the three pillars of sustainability: economic development, considering the production of ornamental plants and similar species, which is currently in full expansion and whose demand is highly concentrated in large cities; social development, by the inclusion of family farmers in the process, generating additional income and thus contributing to their welfare, and; environmental development, as a viable alternative to reduce the pollution load over streams and rivers, especially in large cities, many of them still lacking sanitation policies and facilities.

Currently, many flowers are produced mainly in the so-called semihydroponic systems, where in general an inert substrate supports plants and, along with roots, receives both fertilization and irrigation. There is no contact between substrate and roots with commercial parts, in the case of cut flowers, flowers or inflorescences and floral spikes. This system considerably reduces the contact of both farmers and end products with reuse water, resulting in efficiency and safety. Several and diverse ornamental species may be grown in this system, even bulb flowers, such as gladiolus (Gladiolus x grandiflorus), beautiful flowers widely used in celebrations and festive occasions (Figure 1). Gladiolus is easy to grow, since it does demand large areas, has short cycle and, as far as Brazil is concerned, it is well and broadly adapted to the environmental conditions (Paiva et al., 1999). This set of characteristics turns gladiolus into one of the best bets for hydroponic systems with treated sewage water.

\section{The synergy between ornamental} plants and reuse water

It is true that there is great need for more research on the subject. Here, however, our purpose is to highlight the potential of combining two themes of high economic and environmental interest, i.e. the hydroponics or semihydroponics production of ornamental plants and the use, for this purpose, of recycled water. This match paves the way for using an alternative water source in the horticulture, saving fertilizers, increasing farmer incomes and decreasing the volume of wastewater discharged directly into watercourses.

In addition to flower production, landscaping projects, either private or public, are also a good match between recycled water and urban horticulture. In such projects, domestic treated sewage waters are directed to the respective gardens and surroundings, reducing the pollution load of urban waterways. Among the benefits we highlight the maintenance and increase of green areas, including urban afforestation, crucial for mitigating heat islands in cities, with no increases in clean water demand. In addition, the use of wastewater allows reducing the sewage volume transported over long distances, as well as the volume that needs treatment, several times inefficient and often expensive, with many maintenance and leakage problems. Moreover, it contributes to reduce the sewage release in natura, which pollutes waterways that should be preserved for catching clean water. Finally, wastewaters also function as nutrient sources for plants, supporting a more abundant development and thus contributing to improve the general appearance of large cities and to reduce the feeling of concrete deserts.

\section{Some necessary precautions}

A study on the potential for soil salinization of reuse wastewater in medium to long term must precede its effective use (Qian, 2006). Nevertheless, independent of this effect, landscapers have almost always the opportunity to choose plants more tolerant to salinity or able to accumulate salt in their parts. Examples of such plants are Atriplex nummularia (known as saltbush) (Leal et al., 2008) and seashore plants, such as Suaeda maritima which, beyond surviving in saline conditions, also reduces soil salinity and uptakes soluble salts in soils irrigated with reuse water (Saiyood et al., 2012). There are also very common grass species, used in gardens in different parts of the world including Brazil, which are to a certain extent tolerant to salinity, such as Paspalum vaginatum, Zoysia japonica and some genotypes of Cynodon dactylon (Uddin \& Juarimi, 2013).

Different genotypes of the same species may be more or less tolerant to salinity and it is possible to develop cultivars with higher tolerance levels through breeding. Thus, breeding can also contribute to the use of less noble waters for irrigation in landscaping initiatives, allowing for combining environmental sustainability to technical implementation viability. It is also possible, and advisable, to draw up lists of more adapted species, similar to that developed by the University of California on plants tolerant to reuse water and salinity (Wu \& Dodge, 2005). These databases are important sources of information, aiding landscaping professionals in the implementation of projects involving the use of recycled water.

Wastewater may also be used to produce pot flowers, provided that the water undergoes a previous physical or chemical treatment to reduce or eliminate the contamination sources to 
Table 1. The World Health Organization recommendations* on the microbiological quality of reuse water intended for agriculture (recomendações* da OMS para a qualidade microbiológica de águas residuais empregadas na agricultura). Araras, UFSCar, 2016.

\begin{tabular}{|c|c|c|c|c|c|}
\hline Class & Agricultural use & Risk group & $\begin{array}{l}\text { Intestinal helminths }{ }^{1} \\
\left(\mathrm{n}^{\mathrm{0}} \cdot \mathrm{eggs} / \mathrm{L}\right)^{2}\end{array}$ & $\begin{array}{c}\text { Fecal coliforms } \\
(\mathbf{n} / 100 \mathrm{~mL})\end{array}$ & $\begin{array}{l}\text { Recommended } \\
\text { treatment }\end{array}$ \\
\hline A & $\begin{array}{c}\text { Crops to be } \\
\text { consumed in natura, } \\
\text { sports fields and } \\
\text { public parks }\end{array}$ & $\begin{array}{l}\text { Workers, } \\
\text { consumers, } \\
\text { public }\end{array}$ & Up to 1 & Up to 1000 & $\begin{array}{c}\text { Tandem stabilization ponds } \\
\text { or equivalent }\end{array}$ \\
\hline B & $\begin{array}{l}\text { Cereals, industrial } \\
\text { crops, pastures and } \\
\text { trees }\end{array}$ & Workers & Up to 1 & Not established & $\begin{array}{l}8-10 \text { day retention in } \\
\text { stabilization ponds or } \\
\text { removal of helminths and } \\
\text { fecal coliforms }\end{array}$ \\
\hline $\mathrm{C}$ & $\begin{array}{c}\text { Same as B, when } \\
\text { there is no contact } \\
\text { with workers and the } \\
\text { public }\end{array}$ & None & Not established & Not established & $\begin{array}{l}\text { Pre-treatment required by the } \\
\text { selected irrigation system, } \\
\text { but never less than the } \\
\text { primary treatment }\end{array}$ \\
\hline
\end{tabular}

*In specific situations, epidemiological, sociocultural or environmental factors must be considered and the guidelines adapted accordingly (em casos específicos, fatores epidemiológicos, socioculturais ou ambientais devem ser levados em consideração e essas diretrizes modificadas de acordo). ${ }^{1}$ Ascaris, Trichuris, Necator americans and Ancilostomus duodenalis; ${ }^{2}$ Arithmetic average during irrigation (média aritmética durante o período de irrigação); ${ }^{3}$ Geometric average during irrigation (média geométrica durante o período de irrigação); ${ }^{4}$ more restrictive standard values (200 fecal coliforms/100 mL) are appropriate for public lawns where people have direct contact, such as in hotels (valores diretrizes mais restritivos, 200 coliformes fecais $/ 100 \mathrm{~mL}$, são apropriados para gramados públicos com os quais o público tenha contato direto, tais como em hotéis); ${ }^{5}$ For fruit trees, irrigation should cease two weeks before harvest and no fruits are to be harvested from the ground. Avoid sprinkling irrigation (para fruteiras, a irrigação deve cessar duas semanas antes da colheita e os frutos não devem ser colhidos do chão. Irrigação com aspersores não deve ser utilizada).

final consumers. Currently, ultraviolet light and chlorine-based products, such as the stabilized liquid chlorine dioxide $\left(\mathrm{ClO}_{2}\right)$, are very efficient, the latter even when used at very low concentrations (Cardoso, 2009; Cardoso \& Teixeira da Silva, 2012). $\mathrm{ClO}_{2}$ is also considered an excellent disinfectant, with bactericidal and fungicide action. It does not form toxic chloramines, being safe to animals and stable over a wide $\mathrm{pH}$ range, from 3.0 to 9.0 (Junli et al., 1997; Aquastel, 2009). The product works well in the presence of reuse water, since, in most cases, reuse water $\mathrm{pH}$ ranges in average from 6.6 to 8.2 , depending on the type of effluent (primary or secondary) and treatment applied (biofilter, stabilization pond, etc.). Cuba et al. (2015) observed $\mathrm{pH}$ values of 6.6 and 8.3 for treated wastewater with and without supplementation with fertilizer, respectively, used in lettuce in hydroponics. It is important to remember that, if $\mathrm{pH}$ is out of the optimal range for a given crop, it can result in reduced root growth and, consequently, poor plant development. Thus, adjustments in $\mathrm{pH}$ and also in electrical conductivity
(EC) and nutritional formulation might be necessary to increase the water use efficiency in irrigated or fertigated production systems based on reuse water, aiming at enhancing the general system sustainability.

\section{Safety in the use of recycled water in production systems}

It is important to know the main existing techniques for removing bacteria and helminths present in wastewater, enabling its broad use in irrigation and ensuring the safety of final consumers and workers. In Brazil, with a predominant tropical climate, stabilization ponds are the most attractive and suitable means for treatment of sewage effluents for agricultural purposes (Fernandes, 2015). Ponds, which are built in tandem and formed by sequential anaerobic, facultative and maturation units, with average hydraulic retention times of 10 to 30 days (depending on the temperature), are used to meet the guidelines of the World Health Organization both for fecal coliforms and helminths (Hespanhol, 2002).
The closer farmers and consumers are from the pollution source, the higher the risks of contamination if proper treatments are not applied. Therefore, whenever possible, health protection measures must be associated with effluent treatment, among them:

- Crops with less potential for contamination of workers and farmers;

- Wastewater application techniques that minimize the risks of contamination of plants and workers, such as drip irrigation;

- Hygiene practices and thorough product cleaning;

- Medication (e.g. anthelminthic) and immunization;

- Use of personal protective equipment, and;

- Restricted access to fields irrigated with recycled water.

\section{Final considerations}

The use of recycled water in agriculture becomes, each day, a more viable alternative to meet society biddings to orchestrate economic development and environmental 
preservation. Nevertheless, it is not easy to estimate the extent of the current cultural impediment to the use of wastewater in horticulture. It is definite that its use in the production of ornamental species, including flowers, intended for landscaping, is a way to be further studied and chased, especially where urban horticulture is fostered. In Brazil, the incentive of the National Irrigation Policy, the current water crisis and the unstable weather conditions experienced in the Northeast, Midwest and Southeast make this path even more attractive, if not urgent.

To progress in this endeavor, the practice of reuse must be included in national management plans of water resources, strictly recommending the use of recycled water where and when clean water is not available or is difficult to obtain. On the other hand, the unplanned use of recycled water, even if unconscious, must be monitored and prohibited in order to avoid drawbacks in public health and environmental problems.

The need for developing and implementing projects involving reuse water in urban and peri-urban agriculture is imperative. Nevertheless, it is essential to previously gather data and results and to monitor consequences in experimental units. Experimentation will allow the establishment of local criteria for the use of wastewater and the development of standards and best practices. This will favor research, extension, capacity building and, thus, the expansion of the initiative, leading to increase sustainability with compliance to the latest technical guidelines and the most update production systems. It is worth mentioning the city of Santa Rosa, in California (USA), which currently uses $98 \%$ of treated recycled water to irrigate about 2600 hectares (6400 acres) of farms, vineyards and public urban landscaping areas (City of Santa Rosa, 2016). Santa Rosa is only one among many other cities that already use recycled water as part of their productive process, aiming at building a sustainable horticulture. Examples such as the Santa Rosa only confirm that, yes, we can!

\section{ACKNOWLEDGEMENTS}

Authors thank William Naves Duarte, undergraduate student in Plant Production and Associated Bioprocesses (Federal University of São Carlos, Center of Agrarian Sciences) for the gladiolus pictures granted to this paper.

\section{REFERENCES}

ANVISA - AGÊNCIA NACIONAL DE VIGILÂNCIA SANITÁRIA. 2001, 10 de fevereiro. Resolução-RDC $n^{\circ}$. 12, de 02 de janeiro de 2001. 13 de junho. Disponível em: http://www.portal.anvisa.gov.br

AQUASTEL. 2009. Propriedades dos desinfetantes da água. 13 de junho. Disponível em: http://www.aquastel.com.br

BASTOS, RKX. 1999. Fertirrigação com águas residuárias. In: Folegatti, MV (ed). Fertirrigação: Citrus Flores Hortaliças. Guaíba: Livraria e Editora Agropecuária Ltda p.279-291.

CARDOSO, JC. 2009. Esterilização química de meio de cultura no cultivo in vitro de antúrio. Pesquisa Agropecuária Brasileira 44: 785-788.

CARDOSO, JC; TEIXEIRA DA SILVA, JA. 2012. Micropropagation of gerbera using chlorine dioxide $\left(\mathrm{ClO}_{2}\right)$ to sterilize the culture medium. In vitro Cellular \& Developmental Biology. Plant 48: 362-368.

CETESB - COMPANHIA AMBIENTAL DO ESTADO DE SÃO PAULO. 2001. Orientação para apresentação de projeto visando a aplicação de água de reuso proveniente de estação de tratamento de esgoto doméstico na agricultura. Aplicação de água de reuso de ETE na agricultura. 13 de junho. Disponível em: http://www.cetesb.sp.gov.br

CITY OF SANTA ROSA. 2016. Recycled water links. 13 de junho. Disponível em: http:// ci.santa-rosa.ca.us/departments/utilities/ recycle/Pages/faq.aspx

CUBA, RS; CARMO, JR.; SOUZA, CF; BASTOS, RG. 2015. Potencial de efluente de esgoto doméstico tratado como fonte de água e nutrientes no cultivo hidropônico de alface. Revista Ambiente e Água 10: 574-586.

DE BON, H; PARROT, L; MOUSTIER, P. 2010. Sustainable urban agriculture in developing countries. A review. Agronomy for Sustainable Development 30: 21-32.

FERNANDES, C. 2015. Digestão Anaeróbica. 13 de junho. Disponível em: http://www.dec.ufcg. edu.br/saneamento/DigeAnae.html
GUIMARÃES, AM; ALVES, EGL; FIGUEIREDO, HCP; COSTA, GM; RODRIGUES, LS. 2003. Freqüência de enteroparasitas em amostras de alface (Lactuca sativa) comercializadas em Lavras, Minas Gerais. Revista Sociedade Brasileira de Medicina Tropical 36: 621-623.

HESPANHOL, I. 2002. Potencial de reuso de água no Brasil agricultura, industria, municípios, recarga de aqüíferos. Revista Brasileira de Recursos Hidricos 7: 75-95.

JUNLI, H; LI, W; NANQUI, R; FANG, M; JULI. 1997. Disinfection effect of chlorine dioxide on bacteria in water. Water Research: 31: 607-613.

LADEIRO, B. 2012. Saline agriculture in $21^{\text {st }}$ century: Using salt contamined resources to cope food requirements. Journal of Botany 2012: 1-7.

LEAL, IG; ACCIOLY, AMA; NASCIMENTO, CWA. 2008. Fitorremediação de solo salino sódico por Atriplexnummularia e gesso de jazida. Revista Brasileira de Ciência do Solo 32: 1065-1072.

LEVIDOW, L; ZACCARIA, D; MAIA, R; VIVAS, D; TODOROVIC, M; SCARDIGNO, A. 2014. Improving water-efficient irrigation: Prospects and difficulties of innovative practices. Agricultural Water Management 146: 84-94.

MATÍNEZ-FERRI, E; SORIA, C; ARIZA, MT; MEDINA, JJ; MIRANDA, L; DOMÍGUEZ, P; MURIEL, JL. 2016. Water relations, growth and physiological response of seven strawberry cultivars (Fragaria $x$ ananassa Duch) to different water availability. Agricultural Water Management 164: 73-82.

PAIVA, PDO; SIMÕES, FC; VIEIRA, FA; FUINI, MG; PAIVA, R. 1999. Cultura do gladiolo. Lavras: UFLA. 27p.

QIAN, Y. 2006. Urban landscape irrigation with recycled wastewater. Colorado State University. 36p. 13 de junho. Disponível em: http://www.cwi.colostate.edu/old/pubs/ series/completionreport/Yaling\%20report $\% 20$ 204.pdf

RASCHID-SALLY, L; JAYAKODY, P. 2008. Drivers and characteristics of wastewater agriculture in developing countries: Results from a global assessment. Colombo, Sri Lanka: International Water Management Institute. 35p. (IWMI Research Report 127).

SAGASTA, JM; MEDLICOTT, K; QADIR, M; RASCHID-SALLY, L; DRECHSEL, P; LIEBE, J. 2013. The safe use of wastewater in agriculture project. In. LIEBE, J; ARDAKANIAN, R. (eds). Proceeding of the UN-WATER project on the Safe Use of Wastewater in Agriculture. Germany: UNWDPC. p.9-38. 
SAIYOOD, S; VANGNAI, AS; INTHORN, AD; THIRAVETYAN, P. 2012. Treatment of total dissolved solids from plastic industrial effluent by halophytic plants. Water, Air \& Soil Pollution 223: 4865-4873.

SOUSA, JT, CEBALLOS, BSO, HENRIQUE, IN, DANTAS, JP, LIMA, SMS. 2006. Reuso de água residuária na produção de pimentão (Capsicum annuum L.). Horticultura Brasileira 24: 89-96.

TRESSELER, JFM; FIGUEIREDO, EAT;
FIGUEIREDO, RW; MACHADO, TF; DELFINO, CM; SOUZA, PHM. 2009. Avaliação da qualidade microbiológica de hortaliças minimamente processadas. Ciência e Agrotecnologia 33: 1722-1727.

UDDIN, MK; JURAIMI, AS. 2013. Salinity tolerance turfgrass: history and prospects. The Scientific World Journal 2013: 1-6.

UNO - United Nations Organization. 2006, 5 de março. World Urbanization Prospects: The 2005 Revision. 13 de junho. Disponível em: http://www.un.org

WHO - World Health Organization. 1989. Health Guidelines for the Use of Wastewater in Agriculture and Aquaculture. 13 de junho. Disponível em: http://apps.who.int

WU, L; DODGE, L. 2005. Landscape plant salt tolerance selection guide for recycled water irrigation. 13 de junho de 2016. Disponível em: http://slosson.ucdavis.edu/files/215300.pdf 